\title{
Biomass Partitioning in 'Caucasian' and 'WW-Spar' Old
} World Bluestems

\author{
P.I. COYNE AND J.A. BRADFORD
}

\section{Abstract}

Above- and belowground biomass dynamics of 'WW-Spar' (Bothriochloa ischeemum) and 'Caucasian' (B. caucasica) Old World bluestems were monitored under field conditions during spring-summer and summer-fall growing cycles in 1983. The objective was to document biomass partitioning patterns to complement earlier studies of leaf physiology and aboveground growth behavior in these 2 grasses. The standing crop of forage reached 500 and $694 \mathrm{~g} \mathrm{~m}^{-2}$ in WW-Spar and Caucasian, respectively, by the end of cycle 1 (11 July 1983). However, as in earlier studies, Caucasian was more sensitive to limited soil water so that its forage production and water-use efficiency showed a much greater decline in the second cycle than did these parameters in WW-Spar. At reproductive maturity, both grasses partitioned about 0.4 of total biomass to aboveground compartments (leaves, stems, stem bases, inflorescences) with Caucasian allocating more of its aboveground biomass to leaves and stems and WW-Spar more to stem bases. Excluding stem bases from the aboveground compartment showed that WW-Spar had the higher leaf/stem ratio. Root biomass declined significantly at the start of each growing cycle, but was similar in both grasses (peak root standing crop $=1,900 \mathrm{~g} \mathrm{~m}^{-2}$ to $\mathrm{a}$ depth of $1.2 \mathrm{~m}$ ). Caucasian tended to partition slightly more of its root biomass to upper soil layers, WW-Spar more to lower layers. Across growing cycles and species, 0.56 of total root biomass was in the 0 to $0.1 \mathrm{~m}$ layer, 0.73 between 0 and $0.2 \mathrm{~m}$, and 0.84 between 0 and $0.4 \mathrm{~m}$. Regression analysis indicated that roots should be sampled to $0.4 \mathrm{~m}$ to account for $90 \%$ of the variation in roots to the $1.2 \mathrm{~m}$ depth. Net root production was estimated to be 495 and $753 \mathrm{~g}$ $\mathrm{m}^{-2}$ in cycle 1 for WW-Spar and Caucasian, respectively, and 366 and $388 \mathrm{gm}^{-2}$ in cycle 2 . Relative growth rates (RGR) of total plant biomass were similar in both grasses and increased linearly during each growing cycle to values between 0.01 and $0.02 \mathrm{~g} \mathrm{~d}^{-1} \mathrm{~g}^{-\mathrm{P}}$. Increases in RGR early and late in a growing cycle were supported by increases in efiiciency of the photosynthetic apparatus (unit leaf rate). Mid-cycle increases in RGR were more dependent on expansion in the size of the photosynthetic apparatus (leaf area ratio) as unit leaf rate remained constant during this time. In addition to physiological differences found in earlier studies, this study suggested that variations in drought performance between these 2 grass species may also be related to morphological differences, primarily the tendency of WW-Spar to partition more of its root biomass to lower depths in the soil profile than Caucasian and perhaps the much greater crown or basal area of WW-Spar compared to Caucasian.

The Old World bluestems (OWB, Bothriochloa spp.) are being integrated into forage-based beef production systems of the Southern Plains, particularly on farmed-out soils as a complement to native range, because of their stand persistence, drought performance, and relatively high production. Recent advances in seed harvesting and processing technology have facilitated the acceptance of these grasses (Dewald and Biesel 1983a,b). Forage production of OWB monocultures at Woodward, Okla., is typically fourfold greater than native range when both are managed according to recommendations (Sims and Dewald 1982).

\footnotetext{
Authors are plant physiologist, Southern Plains Range Research Station, USDA/ARS, 2000-18th Street, Woodward, Okla. 73801. Current address of first author is Fort Hays Experiment Station, Kansas State University, Hays 67601.

Manuscript accepted 14 November 1985.
}

Two cultivars, currently being used commercially, have been the subjects of earlier investigations dealing with aboveground growth characteristics and leaf photosynthesis and water relations (Coyne et al. 1982, Coyne and Bradford 1985). Results of these studies serve as background and initiative for this study. 'Caucasian' bluestem (B. caucasica (Trin.) C.E. Hubb) was introduced into this country from Tiflis (Tbilisi), U.S.S.R. (Harlan 1952). 'WW-Spar' (B. ischaemum (L.) Keng. var. ischaemum) was introduced from Pakistan (Harlan 1963) and is one of 30 yellow bluestem components blended to make 'Plains' bluestem (Taliaferro et al. 1972). Because of its superior drought performance compared to the other components of Plains, WW-Spar was released as a singlecomponent variety in 1982 (Dewald et al. 1985).

An earlier study which dealt only with aboveground growth characteristics of 4 OWB's, including Caucasian and WW-Spar, (Coyne and Bradford 1985) confirmed the differences in drought performance between these grasses. Partitioning of biomass to leaves and stems and the biochemical costs of new leaf tissue (biomass and nitrogen per unit leaf area) were similar in both grasses when compared as means of growth cycles, although seasonal trends in these parameters were frequently different.

Because little was known about the belowground component of the Old World bluestems, this study was conducted to compare growth and partitioning in the entire plant (both above- and belowground) and to document cycles in the absolute pool sizes as well as concentrations of nitrogen and nonstructural carbohydrate reserves. The objective was to develop a more complete understanding of the physiology and morphology of these grasses, particularly the belowground component, to complement earlier findings on differences in leaf water-use efficiency and aboveground growth patterns. Growth, water-use efficiency and biomass partitioning data are reported here. Nitrogen and carbohydrate data will be the subject of a subsequent paper.

\section{Materials and Methods}

\section{Plant Materials and Culture}

Above- and belowground biomass of 'Caucasian' (Accession WW-758) and 'WW-Spar' (WW-573) were sampled repetitively during the 1983 growing season. Both grasses are apomictic so the sampled population of each species was genetically uniform. These selections were 2 of 16 entries in a randomized complete block ( 8 blocks) field nursery established from seedling transplants at Woodward, Okla. in 1978. The Hardeman soil (coarse-loamy, mixed thermic typic Ustocrept) was fertilized annually, beginning in 1978 , with $67 \mathrm{~kg} \mathrm{~N} \mathrm{ha}^{-1}$ as $\mathrm{NH}_{4} \mathrm{NO}_{3}$ in a split (April, July) application. The nursery was burned each year in March prior to growth initiation. Plots consisted of 5 rows of 20 plants ( 1 entry/plot). Spacing was $0.3 \mathrm{~m}$ ( 1 foot) between plants within a row and between rows. Average area occupied by each plant was $0.0929 \mathrm{~m}^{2}$ ( 1 square foot). Aluminum access tubes were centrally located in each plot and used to measure water content on a regular basis by the neutron attenuation method at the mid-point of $0.2-\mathrm{m}$ increments to a depth of $2.6 \mathrm{~m}$.

\section{Field Sampling Scheme}

Growth was monitored by periodic harvests of randomly chosen subsets of plants during a spring-summer and summer-fall growth cycle (hereafter cycle 1 and cycle 2, respectively) in 1983. The 2 sequential growth cycles were representative of management situa- 
tions in which the grass is harvested for hay. Blocks 1 through 4 were used for cycle 1 and blocks 5 through 8 (which grew undisturbed during cycle 1) for cycle 2 in order to have sufficient, undisturbed plant material for repetitive sampling. Following spring growth initiation (11 April 1983), plants were sampled 12 times during cycle 1: 18 April; 2, 9, 16, 23 May; 1, 6, 13, 20, 27 June; and 5, 11 July 1983. Cycle 1 was terminated when the plants had developed mature seed stalks and Cycle 2 was then initiated by mowing the plots in blocks 5 through 8 to a stubble height of about $30 \mathrm{~mm}$ on 14 July 1983. Samples were taken 9 times during cycle 2: 14 July; 1, 15, 22, 30 August; 9, 19, 29 September; and 10 October 1983. A random sampling plan identified plants from the center 3 rows of each plot (excluding border plants on either end) for each succeeding harvest date. Since coring the soil to sample root biomass (described below) might potentially affect adjacent plants, individuals to be sampled were restricted to only even numbered plants in the outside rows and odd numbered plants in the center row. A plant was used only once during the experiment.

Two plants per plot (block) were sampled for each species and sample date. Aboveground biomass was severed at the top of the crown (about 20 to $30 \mathrm{~mm}$ above the soil surface) and separated into leaf blades (distal to the collar), leaf sheaths plus enclosed stems, and exerted stems plus infloresences if present. A subsample of leaf blades ( 40 total, 20 from each plant) was collected for determination of leaf blade area. The number of culms represented in the leaf area subsample varied with the leaves per culm, but the subsample always consisted of all leaves on each culm collected in an attempt to represent all leaf ages in proportion to their frequency in the canopy.

Stem bases and roots were subsampled by coring in order to minimize the effect of destructive sampling on the nursery. Although the techniques of sampling grassland roots by coring vary widely, it is a common method for studying belowground biomass of grasses in soil free of rocks (see Bartos and Sims 1974; Sims et al. 1978). Three $25-\mathrm{mm}$ diameter cores were taken per plant: 1 from the middle of the crown and 1 each immediately to the north and south of the crown circumference at the approximate midpoint between adjacent plants. The distance from the sampled plant to its nearest neighbor was the same in all cardinal directions so the choice of the north-south axis was arbitrary. Because this spaced nursery had been growing since 1978 , it was assumed that the overlap of roots among adjacent plants was in steady-state and that the placement of the 3 cores plants ${ }^{-1}$ would adequately sample average belowground biomass on a unit area basis and still minimize damage to the nursery. Cores were taken to a depth of $1.2 \mathrm{~m}$ and stratified into layers of 0 to $0.1,0.1$ to $0.2,0.2$ to $0.4,0.4$ to 0.8 , and 0.8 to $1.2 \mathrm{~m}$. The sampling depth was limited to 1.2 because this was the nominal depth at which it became impractical to drive the coring tool further into the soil. Soil from 2 plants $\times 3$ cores was bulked by depth increment. The 0 to 0.1 increment included both roots and stem bases.

Biomass from both plants within a plot was bulked by tissue fraction and stored on ice while awaiting transportation to the laboratory.

Basal areas were determined from the mean of the north-south and east-west crown diameters and used to calculate total stembase biomass (subsample weight $X$ basal area/sampled area). Total root biomass was calculated by multiplying sampled biomass by the area occupied per plant and dividing by surface area sampled $\left(0.0929 \mathrm{~m}^{2}\right.$ plant $^{-1} / 0.00147 \mathrm{~m}^{2}$ sample $\left.\mathrm{s}^{-\mathrm{I}}=63.2\right)$. Core holes were refilled with topsoil taken adjacent to the plots.

By 10 August, the soil was so dry core samplers could not be driven into the soil. In order to continue sampling, $79 \mathrm{~mm}$ of irrigation water were applied through sprinkler heads at a rate of 5 $\mathrm{mm} \mathrm{h}^{-1}$. This wet the soil to about $0.8 \mathrm{~m}$. Based on soil moisture measurements immediately preceding and 2 days following the irrigation, we estimated that 0.6 of the applied water was stored in the soil. No corrections for the 0.4 discrepancy were made in our

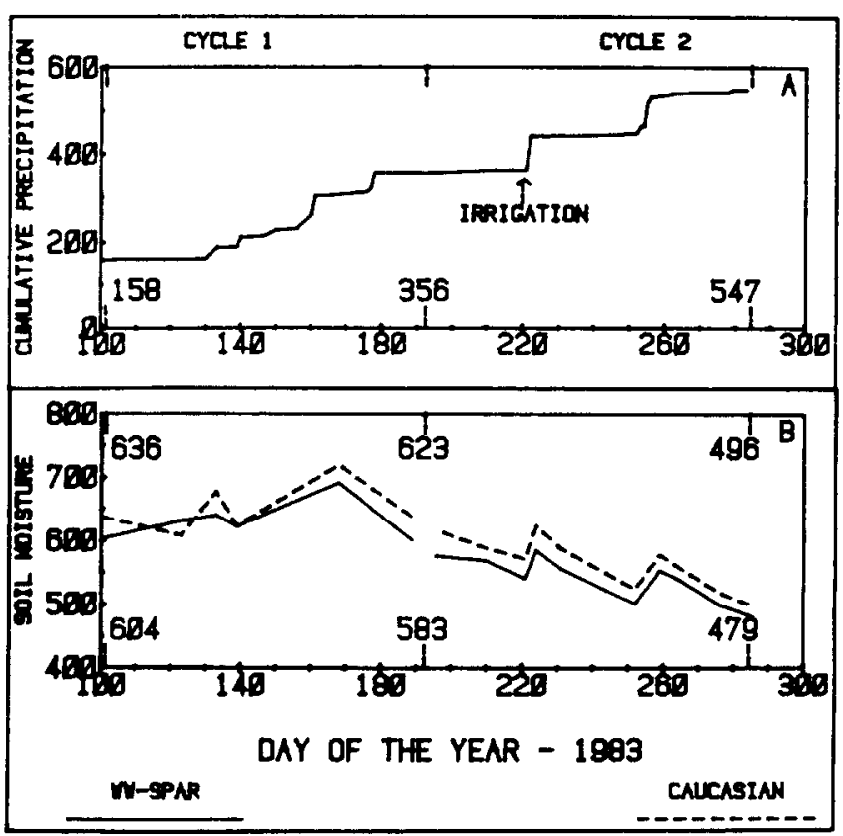

Fig. 1. Cumulative precipitation ( $\mathrm{mm}$ ) and profile (0 to $2.6 \mathrm{~m}$ depth) soil moisture ( $\mathrm{mm}$ ) during 2 growing cycles. Numbers inset in Subfig. A are the digitized values for the beginning and end of each cycle. Numbers inset in Subfig. B represent means across blocks for WW-Spar (bottom) and Caucasian (top) bluestems. These numbers correspond to the means of those used to calculate water-use efficiency (Table 2).

of water-use efficiency (WUE) because precipitation events could not be similarly corrected for runoff or evaporation prior to infiltration and because our primary interest was in relative rather than absolute comparisons of WUE.

Water-use efficiency was calculated by dividing forage production (leaf blades, stems, sheaths, inflorescences measured at the last harvest of each cycle) by evapotranspiration defined as precipitation plus net soil moisture storage (difference in soil profile water content between 0 and $2.6 \mathrm{~m}$ from the start of growth and the last harvest in each growing cycle) during the cycle (Koshi et al. 1982).

\section{Laboratory Analyses}

Total leaf blade area (one side) was determined on the bulked subsample by optical leaf-area meter followed by freeze drying and measurement of dry weight. Specific leaf weight (SLW) was calculated as leaf blade dry weight divided by leaf blade area and was used to calculate total leaf blade area plant ${ }^{-1}$ (total leaf blade dry weight/SLW). Remaining above- and belowground tissue fractions were kept frozen until processed. Root tissue was quantitively separated from soil by a hydropneumatic elutriation system (Smucker et al. 1982) and stem bases were severed from the roots (0-0.1 $\mathrm{m}$ increment) at this time and kept separate during subsequent handling (Sims et al. 1978). All tissue fractions were freeze dried and weighed to determine biomass.

\section{Data Analysis}

Measured and calculated parameter differences between Caucasian and WW-Spar bluestems were determined by analysis of variance with a split on date (Steel and Torrie 1960). Analysis of variance by date was used to highlight the differences between species for a given date that are marked in Figures 2, 3, and 4. Discriminant analyses were conducted using the DISCRIM procedure available from the Statistical Analysis System (SAS) Institute (1979). Growth parameters were derived using the methods of Hunt and Parsons (1974) as previously described (Coyne and Bradford 1985). 


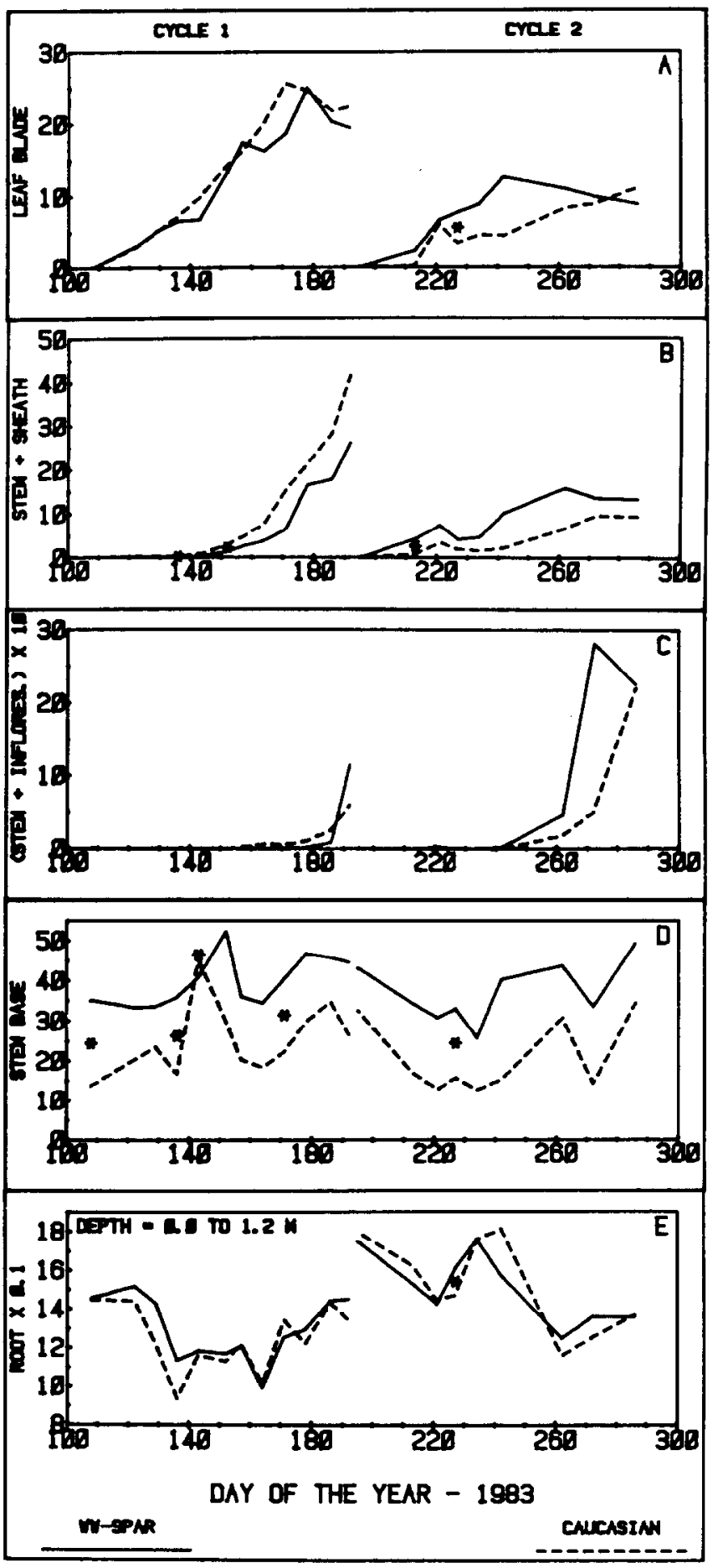

Fig. 2. Comparison of plant biomass ( $g$ plant ${ }^{-1}$ ) in five compartments in WW-Spar and Caucasian bluestems during two growing cycles. Asterisks denote significant differences $(\mathrm{P}<0.05)$ between species within dates. Note that Subfigs. $C$ and $E$ are scaled.

\section{Results and Discussion}

\section{Forage Production and Water-Use Efficiency}

During periods of adequate soil moisture, forage production in Caucasian has been found (Coyne et al. 1982) to exceed that of WW-Spar. However, under drought stress, the relative ranks of these 2 species for forage production reverse, illustrating the ability of WW-Spar to provide a more stable supply of forage during periods of intermittent drought. Similarly, photosynthetic rates on a unit leaf area basis under optimum conditions were generally
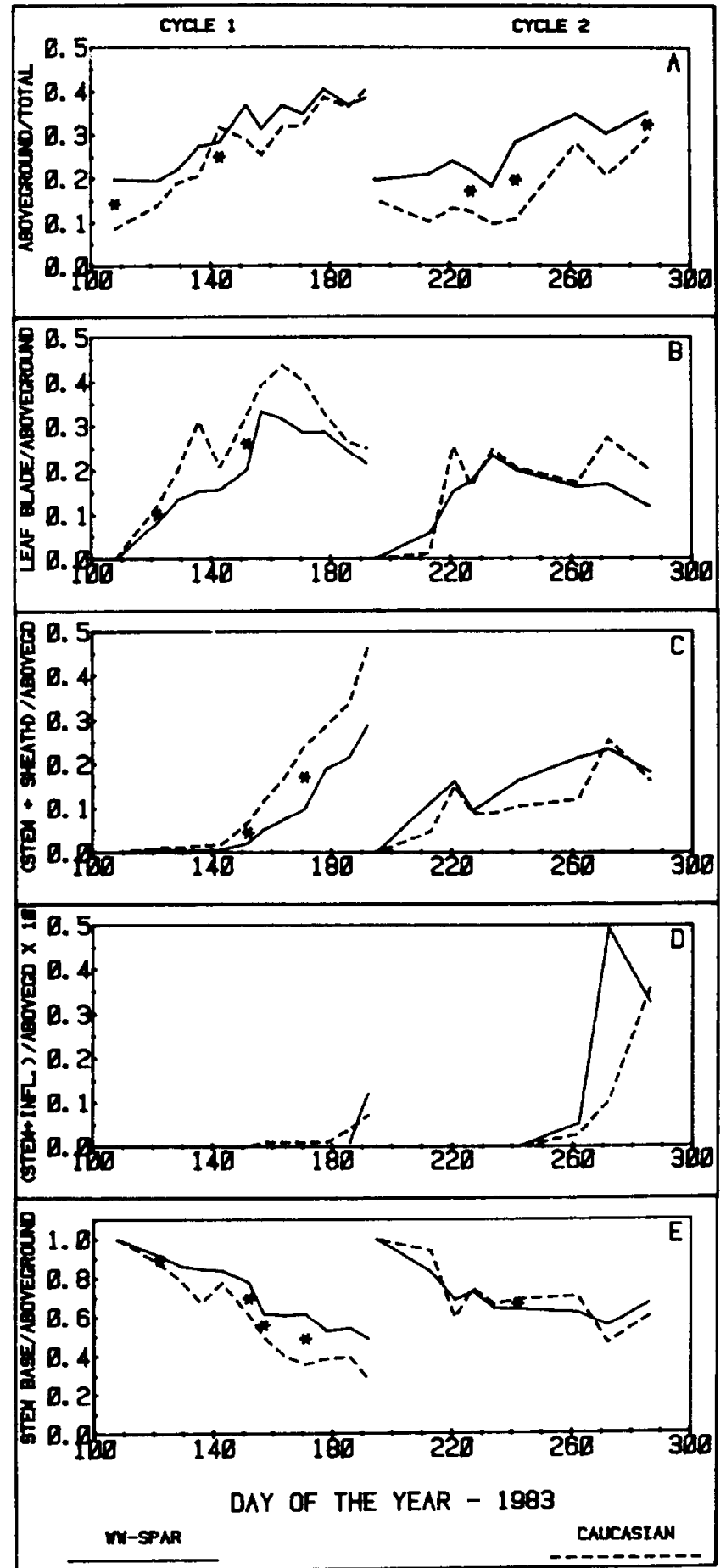

Fig. 3. Comparison of the biomass fraction $\left(\mathrm{g} \mathrm{g}^{-1}\right)$ partitioned among five compartments in WW-Spar and Caucasian bluestems during 2 growing cycles. Asterisks denote significant differences $(\mathrm{P}<0.05)$ between species within dates. Note that Subfig. D is scaled.

higher in Caucasian than in WW-Spar. However, for any given stomatal conductance, photosynthesis was higher in WW-Spar than in Caucasian, resulting in greater leaf WUE in WW-Spar (Coyne et al. 1982). This correlates with the ability of WW-Spar to maintain production further into a soil-drying cycle.

Differences in forage production (leaf blades, sheaths, stems, inflorescences) and WUE between WW-Spar and Caucasian bluestems (Table 1) were less pronounced than in previous studies, but the trend still conformed to earlier results (Coyne and Bradford 1985) in that Caucasian tended to be more productive than WW- 
Spar in the first growing cycle while WW-Spar performed slightly better in cycle 2 . The standing crop of forage continued to increase throughout the growing cycles except for that of WW-Spar in cycle 2 , which peaked on day 262 . Had the peak forage standing crop for WW-Spar been used instead of the terminal cycle value, forage production and WUE would have been 294 and 1.05, respectively, compared to 164 and 0.66 for Caucasian which better illustrates the general WUE advantage of WW-Spar over Caucasian when both are grown under limited soil moisture conditions.

Reasons for less separation between species and cycles in 1983 than previously found in 1982 (Coyne and Bradford 1985) can be explained on the basis of weather. Precipitation (which included

Table 1. Comparison of water-use efficiency during two growth cycles in WW-Spar and Caucasian bluestems.1

\begin{tabular}{|c|c|c|c|c|c|c|}
\hline Entry & Cycle & Precipitation & $\begin{array}{c}\text { Net soil moist. } \\
\text { storage }\end{array}$ & $\begin{array}{c}\text { Evapotrans- } \\
\text { piration }^{3}\end{array}$ & $\begin{array}{c}\text { Forage } \\
\text { production }\end{array}$ & $\begin{array}{l}\text { Water-use } \\
\text { efficiency }\end{array}$ \\
\hline $\begin{array}{l}\text { WW-Spar } \\
\text { Caucasian } \\
\text { P>F }\end{array}$ & 1 & $\begin{array}{l}\mathrm{mm} \\
198\end{array}$ & $\begin{array}{c}\mathrm{mm} \\
21 \\
13\end{array}$ & $\begin{array}{l}\mathrm{mm} \\
219 \\
211 \\
0.85\end{array}$ & $\begin{array}{c}\mathrm{g} \mathrm{m}^{-2} \\
500 \\
694 \\
0.24\end{array}$ & $\begin{array}{c}\mathrm{g} \mathrm{m}^{-2} \mathrm{~mm}^{-1} \\
2.34 \\
3.51 \\
0.00\end{array}$ \\
\hline $\begin{array}{l}\text { WW-Spar } \\
\text { Caucasian } \\
\text { P }>\text { F }\end{array}$ & 2 & $191^{2}$ & $\begin{array}{l}104 \\
127\end{array}$ & $\begin{array}{r}295 \\
318 \\
0.56\end{array}$ & $\begin{array}{r}262 \\
243 \\
0.74\end{array}$ & $\begin{array}{l}0.90 \\
0.77 \\
0.32\end{array}$ \\
\hline $\begin{array}{l}\text { WW-Spar } \\
\text { Caucasian }\end{array}$ & $2 / 1$ & 0.96 & $\begin{array}{l}4.95 \\
9.58\end{array}$ & $\begin{array}{l}1.35 \\
1.51\end{array}$ & $\begin{array}{l}0.52 \\
0.35\end{array}$ & $\begin{array}{l}0.38 \\
0.22\end{array}$ \\
\hline
\end{tabular}

'Net soil moisture storage is the difference in profile water content $(0$ to $2.6 \mathrm{~m})$ between the start of growth and the last harvest in each growing cycle. Forage production includes leaf blades, stems, sheaths, and inflorescences measured at the last harvest of each cycle. To compare species within a cycle, $P>F$ is the probability of a type I error. 2Includes $79 \mathrm{~mm}$ irrigation water applied on 16 Aug. 1983 (day=222).

${ }^{3} \mathrm{Sum}$ of precipitation and net soil moisture storage.

Table 2. Morphological parameter means for two growing cycles and the final sampling date of cycle 1 (11 July 1983) for WW-Spar and Caucasian bluestems.

\begin{tabular}{|c|c|c|c|c|c|c|c|c|c|}
\hline \multirow[b]{2}{*}{ Parameter } & \multicolumn{3}{|c|}{$<\longrightarrow$ Cycle $1(\mathrm{~N}=45) \longrightarrow>$} & \multicolumn{3}{|c|}{$<-$ Cycle $2(\mathrm{~N}=31) \longrightarrow$} & \multicolumn{3}{|c|}{$\langle-11$ July $1983(\mathrm{~N}=4) \longrightarrow>$} \\
\hline & WW-Spar & Caucasian & $\mathbf{P}>\mathbf{F}$ & WW-Spar & Caucasian & $\mathbf{P}>\mathrm{F}$ & WW-Spar & Caucasian & $\mathbf{P}>\mathbf{F}$ \\
\hline \multicolumn{10}{|c|}{ Aboveground biomass (g plant ${ }^{-1}$ ): } \\
\hline Leaf blade (Wb) & 12.72 & 14.94 & 0.01 & 7.40 & 5.11 & 0.05 & 19.44 & 22.40 & 0.57 \\
\hline Stem + sheath (Wss) & 6.04 & 10.97 & 0.01 & 8.24 & 4.06 & 0.05 & 26.16 & 41.50 & 0.29 \\
\hline \multirow{4}{*}{$\begin{array}{l}\text { Stem + inflorescence } \\
\text { (Wsi) } \\
\text { Stem base (Wsb) } \\
\text { Total aboveground } \\
\text { (Wag) }\end{array}$} & & & & & & & & & \\
\hline & 0.09 & 0.10 & 0.66 & 0.72 & 0.37 & 0.03 & 1.14 & 0.60 & 0.46 \\
\hline & 40.01 & 25.12 & 0.02 & 37.34 & 21.02 & 0.02 & 44.56 & 26.56 & 0.14 \\
\hline & 58.85 & 51.12 & 0.14 & 56.69 & 30.56 & 0.02 & 91.30 & 91.05 & 0.73 \\
\hline \multicolumn{10}{|c|}{ Root biomass (g plant ${ }^{-1}$ ): } \\
\hline $\mathrm{Wrl}(0.0$ to $0.1 \mathrm{~m})$ & 74.12 & 74.13 & 0.99 & 77.42 & 85.42 & 0.11 & 72.51 & 77.47 & 0.61 \\
\hline $\mathrm{Wr} 2(0.1$ to $0.2 \mathrm{~m})$ & 22.82 & 19.81 & 0.12 & 26.02 & 22.48 & 0.32 & 30.26 & 20.75 & 0.01 \\
\hline$W r 3(0.2$ to $0.4 \mathrm{~m})$ & 13.34 & 13.29 & 0.91 & 17.00 & 16.41 & 0.80 & 18.10 & 15.07 & 0.08 \\
\hline Wr4 (0.4 to $0.8 \mathrm{~m})$ & 9.95 & 10.17 & 0.98 & 18.39 & 18.04 & 0.92 & 14.18 & 12.65 & 0.36 \\
\hline Wr5 (0.8 to $1.2 \mathrm{~m})$ & 9.23 & 6.13 & 0.05 & 12.51 & 9.58 & 0.02 & 10.27 & 8.25 & 0.72 \\
\hline \multicolumn{10}{|l|}{ Total root $(\mathrm{Wr})$} \\
\hline$(0.0$ to $1.2 \mathrm{~m})$ & 129.46 & 123.52 & 0.23 & 151.33 & 151.92 & 0.91 & 145.32 & 134.19 & 0.05 \\
\hline Total plant (Wp) & 188.29 & 174.60 & 0.22 & 204.99 & 182.45 & 0.03 & 236.58 & 225.22 & 0.36 \\
\hline \multicolumn{10}{|c|}{ Biomass partitioning ratios $\left(\mathrm{g} \mathrm{g}^{-1}\right)$ : } \\
\hline Wag/Wp & 0.31 & 0.28 & 0.08 & 0.26 & 0.17 & 0.02 & 0.38 & 0.40 & 0.71 \\
\hline $\mathrm{Wb} / \mathrm{Wag}$ & 0.20 & 0.28 & 0.02 & 0.14 & 0.16 & 0.22 & 0.21 & 0.25 & 0.22 \\
\hline Wss/Wag & 0.08 & 0.15 & 0.00 & 0.14 & 0.11 & 0.06 & 0.29 & 0.46 & 0.11 \\
\hline Wsi/Wag & 0.00 & 0.00 & 0.07 & 0.01 & 0.01 & 0.05 & 0.01 & 0.01 & 0.44 \\
\hline Wsb/Wag & 0.72 & 0.56 & 0.01 & 0.71 & 0.72 & 0.66 & 0.49 & 0.28 & 0.14 \\
\hline Wr1/Wr & 0.57 & 0.60 & 0.30 & 0.51 & 0.56 & 0.21 & 0.51 & 0.58 & 0.19 \\
\hline $\mathbf{W r} 2 / \mathbf{W r}$ & 0.18 & 0.16 & 0.38 & 0.17 & 0.15 & 0.31 & 0.21 & 0.15 & 0.00 \\
\hline $\mathbf{W r} \mathbf{3} / \mathbf{W r}$ & 0.11 & 0.11 & 0.64 & 0.11 & 0.11 & 0.70 & 0.12 & 0.11 & 0.71 \\
\hline $\mathrm{Wr} 4 / \mathrm{Wr}$ & 0.08 & 0.08 & 0.91 & 0.12 & 0.12 & 0.96 & 0.10 & 0.09 & 0.57 \\
\hline $\mathrm{Wr5} / \mathrm{Wr}$ & 0.07 & 0.05 & 0.40 & 0.08 & 0.06 & 0.22 & 0.07 & 0.06 & 0.42 \\
\hline \multirow{2}{*}{\multicolumn{10}{|c|}{$\begin{array}{l}\text { Leaf blade area } \\
\left(\mathrm{m}^{2} \cdot \text { plant }^{-1}\right) \\
\text { Leaf blade area index }\end{array}$}} \\
\hline & 0.25 & 0.29 & 0.01 & 0.14 & 0.11 & 0.15 & 0.35 & 0.38 & 0.75 \\
\hline$\left(m^{2}-n m^{-2}\right)$ & 2.68 & 3.10 & 0.01 & 1.51 & 1.16 & 0.15 & 3.77 & 4.08 & 0.75 \\
\hline
\end{tabular}

'To compare species for a particular parameter within adjacent columns, $\mathbf{P}>\mathbf{F}$ is the probability of a type I error. 


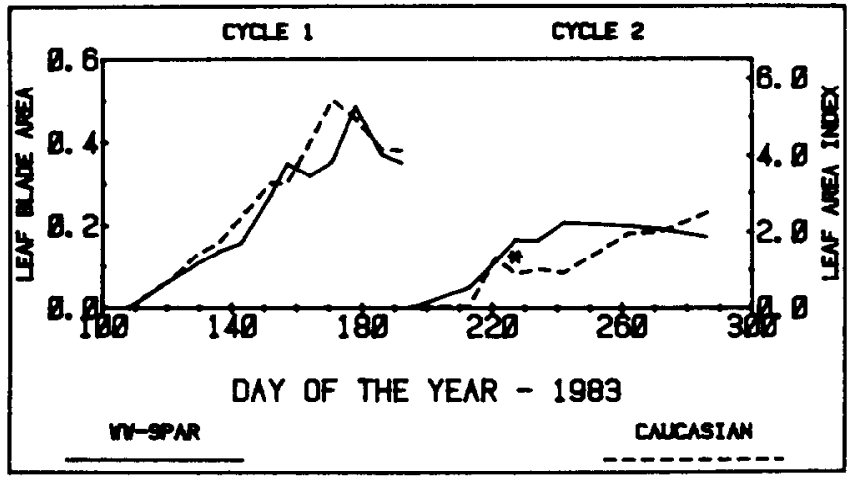

Fig. 4. Comparison of leaf blade area $\left(\mathrm{m}^{2}\right.$ plant $\left.{ }^{-1}\right)$ and leaf area index $\left(\mathrm{m}^{2}\right.$ leaf area $\mathrm{m}^{-2}$ soil surface area) in WW-Spar and Caucasian bluestems. Asterisks denote significant differences $(\mathrm{P}<0.05)$ between species within dates.

irrigation in cycle 2) was more uniform and temperatures more moderate across cycles in 1983 than in 1982. Precipitation in 1982 was 458 and $43 \mathrm{~mm}$ in cycles 1 and 2, respectively, compared to 198 and $191 \mathrm{~mm}$ (Table 1, Fig. 1) in 1983 . However, the ratio of cycle 2/cycle 1 for WUE (Table 1 ) is consistent with the earlier field and laboratory studies (Coyne et al. 1982, Coyne and Bradford 1985) showing the much greater sensitivity of Caucasian to limited soil water compared to WW-Spar.

\section{Biomass Production}

The seasonal progression of biomass (Fig. 2) within growing cycles showed few within date differences between species except for stem bases (Fig. 2d). The greater production of stem bases in WW-Spar compared to Caucasian reflects differences in morphology in these grasses. Caucasian maintained smaller $(P<0.01)$ basal diameters $($ mean $=144 \pm 25 \mathrm{~mm}$ ) than WW-Spar (mean=187 \pm 26 $\mathrm{mm}$ ) even 5 years after establishment. The one reversal (day 143), for which stem-base biomass in Caucasian exceeded that of WWSpar, was apparently an artifact of the randomized sampling scheme in which Caucasian plants at the high end of their basal diameter range and WW-Spar plants at the low end of their range happened to be sampled.

Root biomass (Fig. 2e) decreased about 30\% during growth initiation in cycle 1 and did not begin to recover until the last third of the cycle when reproductive tillers (Fig. 2c) were being produced. Similarly, root biomass declined early in cycle 2 concurrently with the development of a canopy following severe defoliation. Apparent increases in root biomass that began on days 221 and 262 were associated with periods of precipitation or irrigation that resulted in soil moisture recharge (Fig. 1). This suggests an ability of root growth in these grasses to respond rapidly to temporary relief from drought. Peak standing crop of root biomass to a depth of $1.2 \mathrm{~m}$ was similar in both species in both growing cycles and averaged about 1,550 and $1,900 \mathrm{~g} \mathrm{~m}^{-2}$ in cycles 1 and 2 , respectively.

Net root biomass production is commonly calculated by one of 4 methods (Sims et al. 1978). While none of these methods is free of limiting assumptions, Sims et al. concluded that the summation of statistically significant increases in total root biomass was the most reliable. The analysis of variance showed that the $\operatorname{LSD}(P<0.05)$ for total root biomass was 27 and $28 \mathrm{~g} \mathrm{plant}^{-1}$ for cycles 1 and 2 , respectively. Using these values to determine significant increases in total root biomass, we estimated that root production in cycle 1 was 495 and $753 \mathrm{~g} \mathrm{~m}^{-2}$ for WW-Spar and Caucasian, respectively. Corresponding values for cycle 2 were 366 and $388 \mathrm{~g} \mathrm{~m}^{2}$. The cycle 1 values were 2.2 to 3.4 times greater than the annual production values reported for ungrazed True Prairie grassland (Sims et al. 1978) illustrating the propensity of the Old World bluestems to produce more biomass below- as well as aboveground than the warm-season, native, tallgrass species.

Estimates of root production based on biomass data are generally agreed to be low because maxima and minima in root biomass are missed by intermittent sampling schemes and because of unmeasured losses in biomass resulting from root exudation, sloughing, and root grazers (reviewed by Singh et al. 1984). However, based on computer simulations of net root production and subsequent calculations of belowground net production, Singh et al. (1984) showed that variability in root biomass data can lead to overestimation of root production. Thus, the estimates provided above are for purposes of comparison between WW-Spar and Caucasian and should be used with caution in an absolute sense.

Means across dates within cycles (Table 2) revealed that Caucasian had more leaf blade and stem plus sheath biomass than WW-Spar in cycle 1 while the reverse was true in cycle 2 when soil water was more limiting (Fig. 1). Total root biomass was similar in both species in both cycles. Across all compartments, WW-Spar had the greatest standing crop of biomass in both cycles compared to Caucasian and this difference was primarily associated with the stem-base component. Although stems plus inflorescences constituted a relatively minor component of total aboveground biomass, infloresences began appearing about $\mathbf{2 0}$ days earlier in Caucasian than in WW-Spar during cycle 1 . Timing of appearance of reproductive shoots was similar between species in cycle 2 .

Differences between species for root biomass within soil depth increments were significant only in the 0.8 to $1.2 \mathrm{~m}$ layer and were

Table 3. Soll moisture means by depth within a growing cycle for WW-Spar and Caucasian bhestems.'

\begin{tabular}{|c|c|c|c|c|c|c|}
\hline \multirow[b]{2}{*}{ Soil depth } & \multicolumn{3}{|c|}{$<--$ Cycle $1(\mathrm{~N}=72) \longrightarrow>$} & \multicolumn{3}{|c|}{$\langle-$ Cycle $2(\mathrm{~N}=48) \longrightarrow>$} \\
\hline & WW-Spar & Caucasian & $P>F$ & WW-Spar & Caucasian & $\mathbf{P}>\mathbf{F}$ \\
\hline & \multicolumn{2}{|c|}{ - } & & \multicolumn{2}{|c|}{$\ldots \mathrm{mm}-\ldots$} & \\
\hline 0.0 to $0.2 \mathrm{~m}$ & 38 & 36 & 0.035 & 31 & 29 & 0.030 \\
\hline 0.2 to $0.4 \mathrm{~m}$ & 39 & 40 & 0.515 & 31 & 32 & 0.592 \\
\hline 0.4 to $0.6 \mathrm{~m}$ & 40 & 45 & 0.103 & 26 & 30 & 0.030 \\
\hline 0.6 to $0.8 \mathrm{~m}$ & 43 & 47 & 0.028 & 26 & 31 & 0.057 \\
\hline 0.8 to $1.0 \mathrm{~m}$ & 49 & 44 & 0.431 & 30 & 32 & 0.526 \\
\hline 1.0 to $1.2 \mathrm{~m}$ & 47 & 45 & 0.705 & 34 & 37 & 0.669 \\
\hline 1.2 to $1.4 \mathrm{~m}$ & 36 & 46 & 0.098 & 27 & 41 & 0.054 \\
\hline 1.4 to $1.6 \mathrm{~m}$ & 41 & 46 & 0.150 & 37 & 45 & 0.047 \\
\hline 1.6 to $1.8 \mathrm{~m}$ & 53 & 53 & 0.982 & 51 & 50 & 0.910 \\
\hline 1.8 to $2.0 \mathrm{~m}$ & 55 & 55 & 0.849 & 52 & 52 & 0.956 \\
\hline 2.0 to $2.2 \mathrm{~m}$ & 60 & 63 & 0.539 & 58 & 61 & 0.720 \\
\hline 2.2 to $2.4 \mathrm{~m}$ & 67 & 67 & 0.988 & 67 & 68 & 0.906 \\
\hline 2.4 to $2.6 \mathrm{~m}$ & 70 & 71 & 0.675 & 72 & 73 & 0.976 \\
\hline 0.0 to $2.6 \mathrm{~m}$ (total) & 639 & 658 & 0.532 & 540 & 581 & 0.223 \\
\hline
\end{tabular}

ITo compare species within depths, $P>F$ is the probability of a Type I error. 
consistent during both cycles with WW-Spar having the greater root biomass (Table 2 ). This variation in rooting behavior may be biologically significant for explaining the better drought performance of WW-Spar compared to Caucasian in addition to its greater leaf WUE (Coyne et al. 1985) although water contents in the 0.8 to to $1.2 \mathrm{~m}$ layer were not different between species (Table 3). WW-Spar did have lower soil water contents than Caucasian in some of the other soil layers, particularly between 1.2 and $1.6 \mathrm{~m}$ during the drier cycle 2 (Table 3 ). While it is tempting to hypothesize that these differences in soil water contents resulted from greater water extraction by WW-Spar as a result of its greater root biomass at these depths, we could not practically sample roots below the 1.2 depth to make this comparison.

\section{Biomass Partitioning}

Seasonal progressions of partitioning ratios for each growing cycle are graphed in Figure 3. Cycle means and means for final sampling date of Cycle 1 (11 July) are included in Table 2 . The prportion of total plant biomass partitioned to shoots (stem bases, stems, leaves, infloresences) ranged from 0.1 to 0.2 early in a growing cycle to peak values at the end of the cycle of about 0.4 (Fig. 3a, see also peak values in Table 2). During cycle 1 , the ratio of aboveground total biomass for the 2 species averaged about 0.3 with WW-Spar being slightly higher than Caucasian. However, in the drier Cycle 2, WW-Spar continued to maintain an aboveground component equal to 0.26 of total biomass while the Caucasian ratio dropped to 0.17 (Table 2) confirming the better drought performance of WW-Spar. Separation of WW-Spar and Caucasian with respect to partitioning aboveground biomass among the various compartments was primarily limited to the better growing conditions of cycle 1 (Fig. 3b,c,d,e,; Table 2). The more stressful cycle 2 caused the partitioning differences between species to converge. In cycle 1, Caucasian allocated more of its aboveground biomass to leaf blades and stems plus sheaths and less to stem bases than did WW-Spar. However, the large differences in stem-base biomass distort the true picture of partitioning to leaf blades versus stems plus sheaths. The proportion of blades, sheaths, stems, and infloresences partitioned to blades and stems plus sheaths in cycle 1 was 0.57 and 0.42 , respectively, for Caucasian compared to 0.68 and 0.32 for WW-Spar, which agrees with earlier results (Coyne and Bradford 1985).

Across both growing cycles and species, root biomass in the top $0.1 \mathrm{~m}$ averaged 0.56 of total root biomass (Table 2). Corresponding values of 0 to $0.2 \mathrm{~m}$ and 0 to $0.4 \mathrm{~m}$ were 0.73 and 0.84 , respectively. These results are typical of grass root distribution with depth and are well within the range of values reviewed by Risser et al. (1981).
Differences between species were subtle with Caucasian tending to have slightly more of its roots in the upper soil layers and WWSpar tending to have more in the lower layers. The drier second cycle resulted in a slight redistribution of root biomass to lower levels in the soil profile.

Regression equations were calculated to determine the sampling depth required to account for $90 \%\left(R^{2}\right)$ of the variation in total root biomass to a depth of $1.2 \mathrm{~m}$ (Table 4 ). These results indicated sampling to roots to a depth of $0.4 \mathrm{~m}$ would suffice. These equations are by no means to be considered universal and would have to be calibrated for each site and species. In this comparison, species had no significant effects on slope, but did greatly influence the intercepts of these regressions.

Results of a discriminant analysis provide a good summary of the differences in biomass production and partitioning between WW-Spar and Caucasian. Two parameters (biomass of stem bases and roots between 0.8 and $1.2 \mathrm{~m}$ ) were identified that particularly distinguished these 2 grasses. WW-Spar was highest in both parameters.

\section{Leaf Blade Area}

The seasonal progression of leaf blade area and leaf blade area index (LAI) was similar in both species during both growing cycles (Fig. 4, Table 2) although species were significant for a single date in cycle 2 . These similarities in LAI suggest comparable light interception for both species. Leaf area peaked about 2 (WWSpar) to 3 (Caucasian) weeks in advance of the last harvest date in cycle 1 when highest biomass values were observed (Table 2). Peak LAI values were about 5 . The LAI for nearly complete light interception (critical or optimum LAI) varies with species because of different growth forms (Younger 1972). Blaser et al. (1973) stated that there is not an optimum LAI because maximum regrowth [growth] within species plateaus under wide ranges of LAI.

\section{Growth Characteristics}

Relative growth rate (RGR) of total plant biomass (Fig. 5a) is analogous to interest earned on an investment and increased linearly during both cycles with no significant differences between species. The negative values early in each cycle reflect the loss in root biomass (Fig. 2e) as reserves were mobilized to support development of a shoot system. Maximum observed rates of return (or growth efficiencies) were between 0.01 and 0.02 coinciding with highest observed levels of biomass standing crop.

RGR can be partitioned (Evans 1972) into leaf area ratio (LAR, a morphological index relating leaf area to total plant biomass) and unit leaf rate (ULR, a physioloical index relating leaf area to

Table 4. Regression of total root biomass on root biomass in the surface layers of the soil in WW-Spar and Caucasian bluestems during two growing cycles. 1

\begin{tabular}{|c|c|c|c|c|c|c|}
\hline Depth of soil layer & Cycle & Species & $\begin{array}{c}\text { (a) } \\
\text { Intercept }\end{array}$ & $\begin{array}{l}\text { (b) } \\
\text { Slope }\end{array}$ & $\mathbf{R}^{2}$ & Sy.x \\
\hline \multirow[t]{2}{*}{0 to $0.1 \mathrm{~m}$} & 1 & $\begin{array}{l}\text { WW-Spar } \\
\text { Caucasian }\end{array}$ & $\begin{array}{l}596 \\
523\end{array}$ & $\begin{array}{l}1.00 \\
1.01\end{array}$ & $\begin{array}{l}0.77 \\
0.67\end{array}$ & $\begin{array}{l}125 \\
137\end{array}$ \\
\hline & 2 & $\begin{array}{l}\text { WW-Spar } \\
\text { Caucasian }\end{array}$ & $\begin{array}{l}505 \\
373\end{array}$ & $\begin{array}{l}1.35 \\
1.37\end{array}$ & $\begin{array}{l}0.55 \\
0.77\end{array}$ & $\begin{array}{l}167 \\
154\end{array}$ \\
\hline \multirow[t]{2}{*}{0 to $0.2 \mathrm{~m}$} & 1 & $\begin{array}{l}\text { WW-Spar } \\
\text { Caucasian }\end{array}$ & $\begin{array}{l}310 \\
167\end{array}$ & $\begin{array}{l}1.04 \\
1.15\end{array}$ & $\begin{array}{l}0.87 \\
0.87\end{array}$ & $\begin{array}{l}92 \\
86\end{array}$ \\
\hline & 2 & $\begin{array}{l}\text { WW-Spar } \\
\text { Caucasian }\end{array}$ & $\begin{array}{l}133 \\
186\end{array}$ & $\begin{array}{l}1.34 \\
1.25\end{array}$ & $\begin{array}{l}0.77 \\
0.87\end{array}$ & $\begin{array}{l}119 \\
117\end{array}$ \\
\hline \multirow[t]{2}{*}{0 to $0.4 \mathrm{~m}$} & 1 & $\begin{array}{l}\text { WW-Spar } \\
\text { Caucasian }\end{array}$ & $\begin{array}{r}128 \\
23\end{array}$ & $\begin{array}{l}1.07 \\
1.13\end{array}$ & $\begin{array}{l}0.93 \\
0.94\end{array}$ & $\begin{array}{l}69 \\
58\end{array}$ \\
\hline & 2 & $\begin{array}{l}\text { WW-Spar } \\
\text { Caucasian }\end{array}$ & $\begin{array}{r}26 \\
152\end{array}$ & $\begin{array}{l}1.24 \\
1.11\end{array}$ & $\begin{array}{l}0.86 \\
0.93\end{array}$ & $\begin{array}{l}93 \\
85\end{array}$ \\
\hline
\end{tabular}

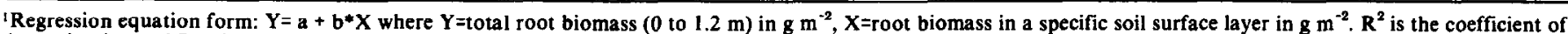

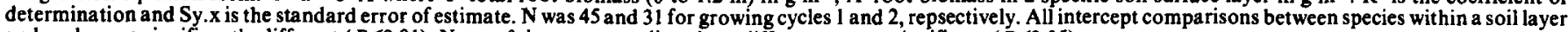
and cycle were significantly different $(P<0.01)$. None of the corresponding slope differences were significant $(P<0.05)$. 

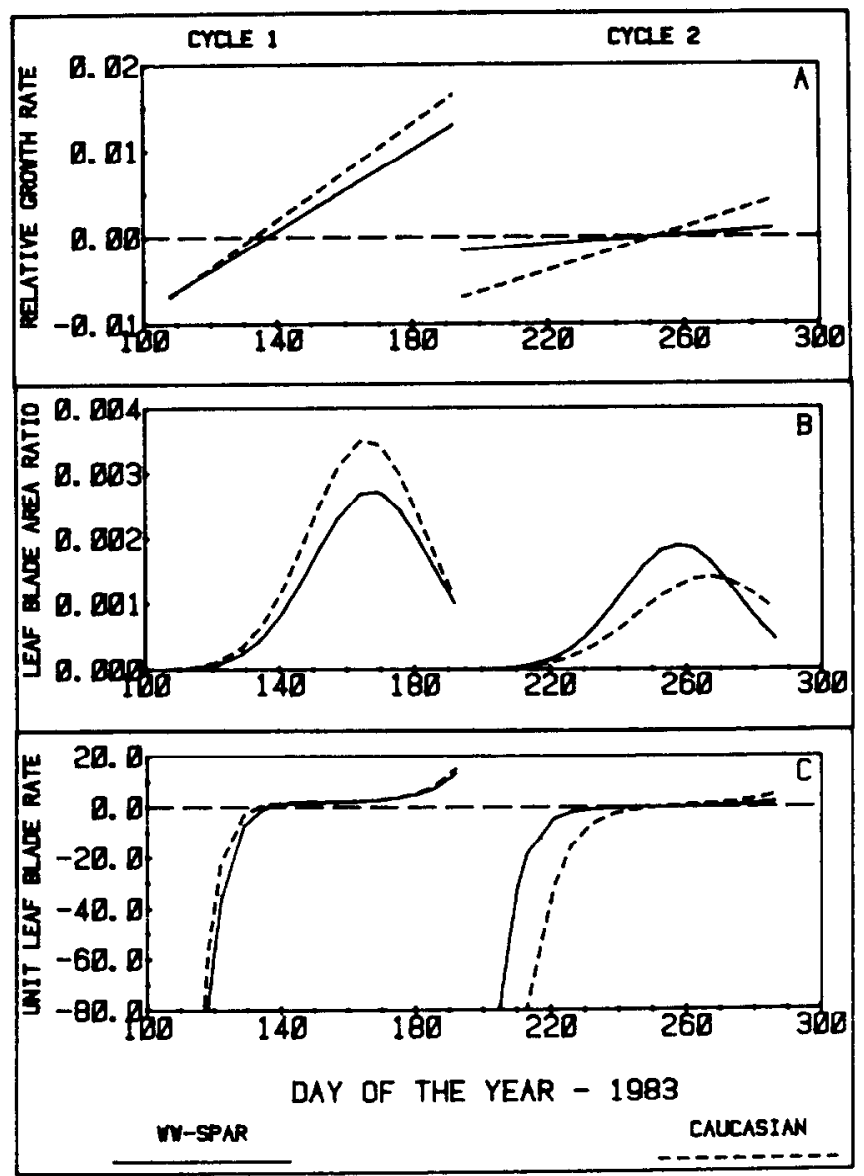

Fig. 5. Comparison of relative growth rate of total plant biomass $[(1 / W p)$ $\left.(d W p / d t), g d a y^{-1} g^{-1}\right]$, leaf blade area ratio $\left[A b / W p, m^{2} g^{-1}\right]$, and unit leaf blade rate $\left[(1 / A b)(d W p / d t), g\right.$ day $\left.{ }^{-1} m^{-2}\right]$ in $W W$-Spar and Caucasian bluestems during 2 growing cycles. Wp=total plant biomass, Ab=leaf blade area, and $t=$ time. Relative growth rate is a product of leaf area ratio and unit leaf rate.

the rate of total plant biomass production) to determine whether physical size or efficiency of the photosynthetic apparatus is the predominant factor controlling growth. Because RGR is the product of LAR (Fig. 5b) and ULR (Fig. 5c), for it to increase linearly throughout both cycles, the plants had to be either increasing the size of the photosynthetic apparatus relative to total plant biomass (LAR) or increasing the photosynthetic efficiency of existing leaves (ULR) or both. The influence of ULR on RGR predominated early and late in the 2 growing cycles, but was constant during mid-cycle when the plants were expanding the size of their photosynthetic apparatus. LAR increased up to the time of peak leaf area in cycle 1 (Fig. 4) indicating that during this period, the relative growth rate of leaf blade area $[(1 / \mathrm{Ab})(\mathrm{dAb} / \mathrm{dt})]$ was greater than the relative growth rate of total plant biomass $[(1 / \mathrm{Wp})$ $(\mathrm{dWp} / \mathrm{dt})]$ where $\mathrm{Ab}=$ leaf blade area, $W p=$ plant biomass, $t=$ time, and $d=$ differential. Beyond peak LAR, the efficiency of new leaf expansion relative to existing leaf area fell below the efficiency of new biomass production requiring an increase in photosynthetic efficiency per unit leaf area to maintain the constant rate of increase in RGR.

These relationships among LAR and ULR have relevance to grazing management in that it may be possible to determine a level of defoliation below which compensatory increases in ULR would offset reductions in LAR and in so doing maintain or even increase the slope of RGR (stimulate growth) compared to its predefoliation value.

The idea that under certain conditions, grazing can actually stimulate aboveground net primary production (NPP) has been termed the 'grazing optimization hypothesis'(Hilbert et al. 1981). The authors reviewed numerous proposed and observed mechanisms to account for the stimulation of NPP including increased photosynthetic rates of remaining tissue (which would cause ULR to increase) and increased proportion of photosynthate allocated to the production of new leaf area (which would cause LAR to increase). Hilbert et al. (1981) described a model based on the relative rates of aboveground biomass which predicted how a plant must respond to grazing if its production is to equal that of an ungrazed plant. The rationale for basing their predictions on relative growth rates of aboveground biomass was its relative simplicity and property of integrating a large number of physiological responses to the environment, including defoliation. Although it is more difficult to acquire the data, it would seem that RGR, as defined in this study along with its components LAR and ULR, would integrate both above- and belowground physiological processes. This should lead to a better understanding of any compensatory responses with respect to either size of efficiency of the photosynthetic apparatus and their resultant effect on the slope of RGR in grazed compared to ungrazed situations.

\section{Conclusions}

We have established from this and earlier (Coyne et al. 1982, Coyne and Bradford 1985) studies that WW-Spar bluestem is superior to Caucasian bluestem in stability of forage production across soil moisture regimes varying from near optimum to drought. Characteristics of these 2 grass species that might account for differences in ability to maintain forage production longer into a drying cycle may be predominantly physiological. Physiological differences include higher leaf water-use efficiency due to more optimal configuration of the resistances in the $\mathrm{CO}_{2}$ pathway and the ability to maintain turgor to lower relative water contents (Coyne et al. 1982). The present study indicated the principal morphological differences in these 2 species were the tendency for WW-Spar to partition more of its root biomass to lower depths in the soil profile compared to Caucasian and the much greater basal area and stem base compartment in WW-Spar relative to Caucasian. The former could confer a competitive advantage in its effect on potential exploitable soil volume and hence soil water extraction and the latter should result in more meristems to re-establish a canopy following defoliation and the potential for larger pools of reserve substances. Other parameters, such as leaf area index and relative growth rates of leaf area and total plant biomass, were not particularly useful in explaining performance differences between these grasses.

\section{Literature Cited}

Bartos, D.L., and P.L. Sims. 1974. Root dynamics of a shortgrass ecosystem. J. Range Manage. 27:33-36.

Blaser, R.E., and D.D. Wolf, and H.T. Bryant. 1973. Systems of grazing management, p. 581-595. In: M.E. Heath, D.S. Metcalfe, and R.F. Barnes (eds.) Forages, 3rd ed. Iowa State Univ. Press, Ames.

Coyne, P.I., and J.A. Bradford. 1985. Some growth characteristics of four Old World bluestems. J. Range Manage. 38:27-33.

Coyne, P.I., J.A. Bradford, and C.L. Dewald. 1982. Leaf water relations and gas exchange in relation to forage production in four Asiatic bluestems. Crop Sci. 22:1036-1040.

DeWald, C.L., and V.A. Beisel. 1983a. The Woodward flail-vac seed stripper. Trans. Amer. Soc. Agr. Eng. 26:1027-1029.

DeWald, C.L., V.A. Beisel, and S. Cowles. 1983b. The Woodward chaffy seed conditioning system, p. 69-80. In: Proc. Range and Pasture Seeding in the Southern Plains. Texas A\&M Univ. Agr. Res. and Ext. Center, Vernon.

Dewald, C.L., P.L. Sims, P.I. Coyne, and W.A. Berg. 1985. Registration of WW-Spar Bluestem. Crop Sci. 25:707.

Evans, G.C. 1972. The quantitative analysis of plant growth. Studies in Ecology. Vol. I. University of California Press, Berkeley.

Harlan, J.R. 1952. Caucasian bluestem (Andropogon caucasicus). Oklahoma Agr. Exp. Sta. Tech. Bull. No. T-72, Stillwater. 
Harian, J.R. 1963. Natural introgression between Bothriochloa ischaemum and B. intermedia in West Pakistan. Bot. Gaz. 124:294-300.

Hilbert, D.W., D.M. Swift, J.K. Detling, and M.I. Dyer. 1981. Relative growth rates and the grazing optimization hypothesis. Oecol. 51:14-18.

Hunt, R., and I.T. Parsons. 1974. A computer program for deriving growth-functions in plant growth analysis. J. Appl. Ecol. 11:297-307.

Koshi, P.T., J. Stubbendieck, H.V. Eck, and W.G. McCully. 1982. Switchgrasses: Forage yield, forage quality, and water-use efficiency. J. Range Manage. 35:623-627.

Risser, P.G., E.C. Birney, H.D. Blocker, S.W. May, W.J. Parton, and J.A. Wiens. 1981. The true prairie ecosystem, U.S. Int. Bio. Prog. Synthesis Ser. 16. Hutchinson Ross Publishing Co., Stroudsburg, Pa.

Sims, P.L., and C.L. Dewald. 1982. Old World bluestems and their forage potential for the Southern Great Plains. A review of early studies. U.S. Dep. Agr., Agr. Res. Serv., Agr. Rev. and Man., Southern Series, ARM-S-28, Southern Regional office, New Orleans.
Sims, P.L., J.S. Singh, and W.K. Lauenroth. 1978. The structure and function of ten western North American grasslands. I. Abiotic and vegetational characteristics. J. Ecol. 66:251-285.

Singh, J.S., W.K. Lauenroth, H.W. Hunt, and D.M. Swift. 1984. Bias and random errors in estimators of net root production: a simulation approach. Ecology 65:1760-1764.

Smucker, A.J.M., S.L. McBurney, and A.K. Srivastava. 1982. Quantitative separation of roots from compacted soil profiles by the hydropneumatic elutriation system. Agron. J. 74:500-504.

Steel, R.G.D., and J.H. Torrie. 1960. Principles and procedures of statistics. McGraw-Hill Book Co., Inc., New York.

Statistical Analysis System (SAS) 1979. SAS User's Guide. SAS Institute Inc., Cary, North Carolina.

Taliaferro, C.M., J.R. Harlan, and W.L. Richardson. 1972. Plains bluestem. Oklahoma Agr. Exp. Sta. Bull. B-699, Stillwater.

Younger, V.B. 1972. Physiology of defolation and regrowth., p. 292-303. In: V.B. Youngner and C.M. McKell (eds.) The Biology and Utilization of Grasses. Academic Press, New York. 